\title{
Role Model for Pursuing an Expansive Science of Behavior: James G. Holland
}

\author{
Thomas S. Critchfield ${ }^{1} \cdot$ R. Douglas Greer ${ }^{2}$ • \\ Kent Johnson $^{3}$ - Joseph E. Morrow ${ }^{4}$. \\ John A. Nevin ${ }^{5}$ - Michael Perone ${ }^{6}$
}

Published online: 21 May 2018

(C) Association for Behavior Analysis International 2018

If one takes seriously B.F. Skinner's contention that the science of behavior is inherently far-reaching, then the scholars in our field who make the best role models are those with appropriately expansive interests and contributions. One such role model, James G. (Jim) Holland, passed away on January 16, 2018.

Jim (Figure 1) may be best remembered for co-authoring with B.F. Skinner a seminal programmed instruction manual, The Analysis of Behavior (1961; soon to be reprinted by the B.F. Skinner Foundation, http://bfskinner.org). This points to one of Jim's many facets: He was a committed teacher who, in nearly 40 years at the University of Pittsburgh, served an estimated 10,000 students (this figure does not include the many students in other countries that he influenced as a guest lecturer and visiting scholar). But there was much more to Jim than his work in instruction.

Jim was also a creative investigator with a knack for posing interesting questions and answering them in ingenious ways, and much of his research was ahead of its time. In the 1950s, when operant laboratories focused almost exclusively on nonhuman behavior, Jim was one of the first to make human subjects the focus of systematic basic research, and the studies he conducted were among the most rigorous of their era. Jim's research on "attention" provided an early model of operationalizing "cognitive" phenomena, and

Authors contributed equally to this paper and are listed alphabetically.

Thomas S. Critchfield

tscritc@ilstu.edu

1 Illinois State University, Normal, IL, USA

2 Teachers College Columbia University, New York City, NY, USA

3 Morningside Academy, Seattle, WA, USA

4 Applied Behavior Consultants, Sacramento, CA, USA

5 University of New Hampshire, Durham, NH, USA

6 West Virginia University, Morgantown, WV, USA 


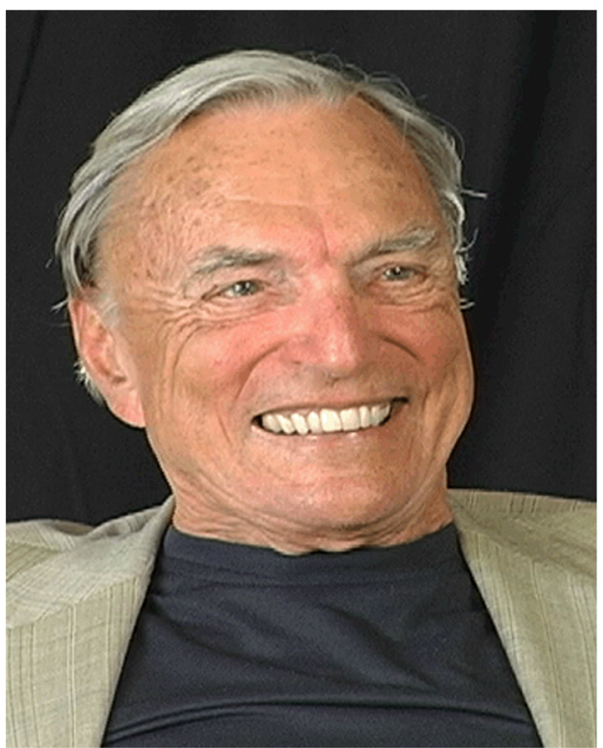

Fig. 1 Jim Holland. Image courtesy of Karen Wagner, from a biographical interview video available on www. thebehavioranalyst.com

because the research was inspired by the U.S. Navy's interest in promoting consistent performance of radar operators, this was expressly translational research, a focus that has received consistent attention in behavior science only recently (Mace \& Critchfield, 2010). The same work also set the stage for later integrations of operant principles with perceptual behavior via signal detection theory (see Nevin, 1969, which is among the all-time mostcited articles from Journal of the Experimental Analysis of Behavior). Long before Don Hake's (1982) well-remembered call for basic researchers to tackle "distinctly human" processes, Jim devised some of the first operant investigations of verbal behavior (e.g., Holland, 1958a), and would later publish the first experimental analysis focusing on Skinner's primary verbal operants (Lamarre \& Holland, 1985).

Around the edges of all of this, Jim was a committed social activist and commentator on the intersection of behavior analysis and social justice issues. In his personal life, he was a devoted husband and father and a long-time member of a Pittsburgh improvisational theater troupe. He will be remembered as much for his civility and kindness as for his specific contributions. As his wife, Pam Meadowcroft, remarked, "He never spoke ill of anyone; he fought over ideas and policies but in the end, even his rivals became friends" (quoted in a January 17, 2018 obituary in the Pittsburgh Post-Gazette).

Because of the breadth of Jim's work, perhaps no single individual is qualified to paint the broad picture of it. Here instead we share a few fragments of observations that, we hope, help to showcase the range of his contributions.

\section{Experimental Analysis of Human Behavior (Contributed by Mike Perone)}

My first acquaintance with the work of James G. Holland was with his early experiments on human operant behavior. This came in my formative years, just as I was 
starting graduate school in 1975, and Holland's work has guided and informed my research ever since.

In the 1950's, Holland was a scientist in the Engineering Psychology Branch of the U.S. Naval Research Laboratory. There he conducted experiments concerned with human vigilance, a matter of some practical significance to the Navy (Holland, 1957; 1958b). The issue was how to sustain the behavior of monitoring an instrument for important but infrequent signals, such as signals of enemy submarines on a radar screen. Holland reasoned that detecting the signals reinforced the behavior of monitoring the instruments, and therefore the schedule of signal detections should determine the frequency and temporal distribution of the monitoring. To test these ideas, Holland required Navy enlisted men to watch a pointer on a meter dial and report deflections of the pointer. Because the room was dark, the only way to see the pointer was by pressing a key that briefly illuminated the meter. When the pointer was deflected, it remained in that position until the man illuminated the meter to detect the signal and then reported the deflection by pressing another key. Pressing the report key also reset the pointer. Each man was told to detect as many pointer deflections as he could and to reset the pointer as rapidly as possible, but the man was never told anything about the schedule.

In Alan Baron's lab at the University of Wisconsin-Milwaukee in 1975, we regarded Holland's vigilance procedure as an intuitively reasonable way to program schedules of reinforcement with adult humans, and we had success with it in experiments with men recruited from industrial labor unions who were promised temporary, part-time employment on a simulated job (Perone \& Baron, 1980; Perone, DeWaard, \& Baron, 1979). Our meter was mounted behind mirrored glass. Responses briefly turned on lamps behind the glass and allowed the man to see the meter. When he saw that the pointer was at 90 degrees, he reported it by pressing a button that reset the pointer and earned some money. With this arrangement, as in Holland's work, the pointer deflections can be programmed according to conventional schedules of reinforcement. On a variable-interval schedule, for example, the reinforcer is set up by deflecting the pointer after the interval has elapsed. The reinforcer comes when the deflection is detected and the pointer is reset, at which point another interval is started.

Holland's (1958b) approach incorporated factors that most researchers now recognize as important in the experimental analysis of human behavior. First, as already noted, the participant's task - the instrumental response - took into consideration the participant's humanity. It had face validity: Monitoring a meter over an extended period of time is a reasonable thing to ask an adult person to do. Second, and more importantly, Holland's vigilance task actively engaged the participant's behavior. As Ferster and Skinner (1957) observed, "The only contact between [a schedule of reinforcement] and the organism occurs at the moment of reinforcement" (p. 2). This contact is uncertain or even absent in a procedure that allows the participant to stare idly into space while tapping a button and advancing a reinforcement counter - a not uncommon situation in the human operant laboratory for many years (and not unheard of today). In Holland's procedure, however, the contact between the participant and the schedule was guaranteed: Reinforcement depended on the participant watching the meter, detecting the pointer deflection, and reporting it. Finally, Holland gave his participants extended exposure to each schedule ( 4 to $8 \mathrm{~h}$ ) before drawing conclusions about the effects.

With these factors in place, Holland achieved impressive results: Performance under a variety of reinforcement schedules closely paralleled what non-human animals 
previously had demonstrated (Ferster \& Skinner, 1957). Given these results showing schedule sensitivity in verbally competent adults, one may wonder why so many took seriously the often-circulated proposition that development of verbal behavior necessarily blocks the effects of reinforcement and produces a discontinuity between the processes governing human and animal behavior. Holland showed us otherwise sixty years ago, and much confusion about human-animal differences might have been avoided had his work been more widely appreciated.

\section{Programmed Instruction (Contributed by Kent Johnson)}

It was a very sad day when I learned that one of the giants in our field, Jim Holland, is no longer with us. He was a very kind and warm-hearted man, one of my first real colleagues back in my early days in our field.

Jim was a pioneer of programed instruction (PI), working with Fred Skinner on The Analysis of Behavior: A Program for Self-Instruction (1961), the first widespread program in behavior analysis for college students. I remember learning about his contributions to programed instruction when I was a graduate student in Educational Psychology. Particularly amazing was his Blackout Technique, a method for determining the extent to which the words in a program were response-contingent or "truly programed." PI researchers would first blacken with a crayon those words in each frame of a program that they thought were unnecessary for occasioning the correct answer. They would then verify their judgment by giving their blackened program to new learners. If those learners achieved an error rate similar to those who completed the program without words blacked out words, then their predictions were validated. Sometimes it was embarrassing for programmers to discover that critical words that logically "should" control learner behavior were unnecessary for occasioning correct responses, and that spurious words actually tipped off the correct response without a careful reading of the entire frame. One of Holland's program investigations found that $90 \%$ of the words in a particular frame were unnecessary for the correct answer!

Jim and his student, Judith Doran, also examined whether blackout ratio (the proportion of "unnecessary" words) affects how thoroughly an instructional frame is read (Doran \& Holland, 1971). They measured eye movements, or fixations, as a measure of attending, and found that when shown frames with a high blackout ratio students read with fewer fixations, shorter fixation time, and shorter scanning time. In other words, frames with a high blackout ratio failed to consistently maintain the students' attending.

Instructional programmers had routinely measured program error rates to validate their instruction, but the Blackout Technique provided a clever additional quantitative research metric. It showed us that while a program may produce a low error rate, it might still not require much of the learner's time and not teach them much, creating a boring experience. I believe that PI's reputation in many circles for being boring was in large part due to so many published programs with high blackout ratios. The Blackout Technique is still highly relevant in designing Internet instruction.

In the early 1970s, Jim became involved in the work of the University of Pittsburgh's Learning Research and Development Center. Here he was exposed to educators who were designing elementary school curricula. These real-world experiences brought him out of the bubble of research in psychology and behavior analysis. 
He spread his experiences to other curriculum developers and behavior analysts by editing a book (Holland, Solomon, Doran, \& Frezza, 1976) that shows how each of our behavior principles - reinforcement, shaping, discrimination training, chaining and the rest - can be recruited to design better instructional materials. It contains a muchrecommended chapter detailing the procedures for the Blackout Technique.

\section{Verbal Behavior and Other Human Complexities (Contributed by Doug Greer)}

My first encounter with Jim Holland occurred when I worked my way through the programmed instruction book that he coauthored with Skinner (Holland \& Skinner, 1961), which I am sure thousands of students have used to learn about behavior analysis. This was soon followed by Schroeder and Holland (1968) on operant control of eye movement; by Wildemann and Holland (1972) on "Control of a continuous response dimension by a conditioned stimulus dimension;" by Holland (1958a) on fixed ratio reinforcement for counting; and by Holland (1958b) on human vigilance. Each of these publications had important influences on my own work. The programmed instruction book taught me the elementary principles of behavior and I used it to do so with many of my own students. The operant control of eye movement and related papers on continuous observing responses suggested a solution to how to measure reinforcement value for listening. This solution resulted in the design of an instrument to measure reinforcement stimulus control of music. The device (operant music listener recorder) was used to study hundreds of participants and eventually resulted in research on the establishment of conditioned reinforcement for observing responses and its subsequent effects on learning and verbal behavior developmental cusps (Greer \& Du, 2015; Greer \& Speckman, 2009).

Lamarre and Holland (1988) was a key early study on verbal behavior and occurred about the time my own laboratory began a program of research on verbal behavior. Skinner (1957) had suggested that mands and tacts were not independent. Holland's work prompted our own our analysis of how the joining of the two functions could be accomplished. Our data across decades affirm that mands and tacts initially are independent but come to be joined as a function of certain experiences (Nuzzolo-Gomez \& Greer, 2004).

The research on observing responses and verbal behavior that Jim's work helped to prompt has supported the development of teaching practices that have been used with many children. For example, building observing responses for book stimuli before teaching textual responses accelerates learning to respond to text significantly (1.5 to 5 times). This has been a practice for more than a decade in our schools (Comprehensive Application of Behavior Analysis to Schools; www.cabasschools.org), in which Jim's work lives on.

I believe I first met Jim in person at the 1979 meeting of the Midwest Association for Behavior Analysis. I attended his presentations and got to know him better through Skinner. I last visited with him and his wife Pam Meadowcroft at a get-together at Ernie and Julie Vargas' house (the Skinner house in Cambridge). I do remember a humorous story that he told me. Apparently, he was summering on Cape Cod and participated in a civil rights parade that resulted in the arrest of the marchers (not an unusual outcome during that era). To his surprise he ended up in a cell with Noam Chomsky! 


\section{“Attention" and Quantitative Analysis (Contributed by Tony Nevin)}

I started graduate school at Columbia in 1959 after 5 years in the Coast Guard, mostly at sea, where vigilance during long watches was essential for routine safety as well as search and rescue missions. So I was delighted to encounter Jim Holland's (1958b) article in Science, showing that vigilance could be treated as operant behavior maintained by detection of targets as reinforcers. Readers who have not encountered this article should have a look: It captures the glory days of behavior analysis, demonstrating reinforcement schedule control over human searching for targets much like that of pigeons (and many other creatures) responding for food. It also argues vigorously for empirical analyses of vigilance rather than lapse into explanatory constructs such as excitatory and inhibitory states, expectancy, and attention.

Holland (1958b) asked Navy enlisted men to press a key that briefly illuminated a dial containing a pointer (observing responses); if the pointer deflected the men were to were report this by pressing a second key (detections). Deflections were scheduled according to various reinforcement schedules, and cumulative records of observing behavior on these schedules were strikingly similar to those reported by Ferster and Skinner (1957) for pigeons pecking a key for food. Holland (1958b) emphasized “... the rather precise control exerted by the environment over the human operator's observing behavior," and went on to suggest that "...in a man-machine system it should be possible for the machine to maintain control over the operator's monitoring behavior" (p. 67) by providing a reliable stream of signals to be detected.

Many years later, having retired from teaching, I sailed from New Zealand to Panama with two friends. At night, two of us took turns in 4-h watches. One night, while I was on watch, sailing due east in perfect weather with nothing in sight, my observing behavior (vigilance) gradually deteriorated over $2-3 \mathrm{~h}$, just as Jim had shown in his research - until, abruptly, a bright light appeared dead ahead. A big ship on collision course? My heart raced as I scrambled for binoculars, got them focused, and discovered that it was the rising moon peering over the horizon. Whew - but my level of vigilance was fully restored, precisely as Jim's work on the reinforcement of observing by signal detection had anticipated.

Extensions of Jim's work on vigilance (Schroeder \& Holland, 1968; Schroeder \& Holland, 1969) played an important early role in encouraging the development of quantitative analyses of behavior. Eye movements became the measured operant, rather than key presses, and the analysis was expanded to include concurrent reinforcement schedules. Participants were asked to monitor four displays and report any time a needle deflected in one of them. Their eye movements were recorded to determine when they looked at the left-hand or right-hand pair of dials, and the needle deflections on these dials were produced on concurrent schedules. The allocation of eye movements to the left vs. right side was analyzed in exactly the same way as for pigeon pecks at the left or right keys in a standard two-key operant chamber, and the results were strikingly similar to what had been reported for pigeons (e.g., Herrnstein, 1961). In the early rush of enthusiasm for quantitative behavior analyses in the 1960s, that was a critical confirmation of the generality of the Herrnstein's matching law of choice behavior.

I have only recently been reminded of the subliminal footprints that Jim's work left on my thinking about behavior. A few years ago I joined Amy Odum and Tim Shahan 
in studying the effects of reinforcer rate on the accuracy and resistance to disruption of conditional discrimination in a procedure where observing responses were required to produce trials. It turned out that the persistence of both accuracy and observing responses depended directly on reinforcer rate for correct responses. Moreover, a quantitative model that treated the covert activities of attending and remembering just like overt operant behavior, and invoked matching to relative reinforcement in DMTS choices, did a pretty good job of accounting for a lot of data (see Nevin, 2008, for review). But in the course of these research studies and quantitative modeling efforts, I did not refer to the influences of Jim Holland's earlier work, and he and I never discussed it. Alas, the role of his work in the development of my own research and quantitative efforts has come clear only with his death.

Outside the laboratory, Jim and I had animated conversations in the 1970s and 1980s about issues of social justice in the USA and its wars in Vietnam and elsewhere. His passionate voice certainly contributed to the persistence of my own protests during those years; now, that voice is sorely needed to counter the shortsighted, dangerous, and cruel policies of our government in these benighted times. We miss him, we need him.

\section{Social Activism (Contributed by Joe Morrow)}

Jim Holland was devoted to social justice. For example, he was a committed and (as a former Marine) rather prominent protester against the Vietnam war who played an important role in linking Pittsburgh anti-war protests to the national movement, including by hosting leaders of the movement at his home. Jim also was supportive of the Cuban Revolution and was part of the Venceramos Brigade, a coalition that challenged U.S. policy toward Cuba in part by traveling there, in defiance of the U.S. embargo, to participate in public works projects. In the 1970s Jim visited Cuba and helped construct homes for workers. He wrote about this experience in the first issue of the Behaviorists for Social Action Journal (Holland, 1978a), ending the article in true Holland form by quoting Che Guevara: "The true revolutionary is guided by strong feelings of love."

Jim paid a price for acting on his principles. Pittsburgh was the home of the U.S. steel industry and therefore of private clubs where the "captains "of the industry hung out. During the Vietnam war, he was part of a group whose picketing and sit-ins disturbed the tranquility of the clubs. Jim told the story that one of these "captains" came over and vomited on him. Jim's university also did not appreciate some of his activities and despite a high level of productivity he remained an Associate Professor for 15 years. The university gradually came to appreciate Jim's contributions and he was eventually elected President of the Faculty Senate. In 2003 he was given a lifetime achievement award for service to the university.

\section{The Ethics of Behavior Control (Contributed by Tom Critchfield)}

I first came across Jim Holland's work in 1980 when taking Applied Behavior Analysis from Pam Meadowcroft, who was at the time teaching the occasional course at West Virginia University, but my initial exposure was not to programmed instruction or 
innovative laboratory experiments. Rather, toward the end of the course we read Holland's (1974), "Political implications of applying behavioral psychology," which asked thorny questions such as who should decide what is "appropriate" target behavior in behavioral engineering and whether employing behavior principles to reduce aversiveness in and increase effectiveness of military training would be considered a good thing if that training were subsequently employed to questionable ends.

I was too young to know that questions about who decides what behavior to reinforce had dogged Skinner from his earliest forays into suggesting applications (e.g., Rutherford, 2000), or that the era in which Holland wrote was a time of emerging self-inspection among behavior analysts about ethical issues (e.g., Goldiamond, 1974; Winett \& Winkler, 1972; Wolf, 1978). Once I went down the rabbit hole opened by Holland (1974), however, it quickly became clear that Jim was among the earliest writers to systematically address some of the key issues (e.g., Holland, 1975, 1976, 1977, 1978b).

The Holland (1974) article resonated with me particularly because, like Skinner, Jim had a special knack for examining issues at the level of social systems. In this article he related the story of

...A visit made by Ronald Reagan, governor of California, to ... Patton State Hospital in California. There he watched with interest the token system used to control ward behavior of psychotic patients. Reagan, who has a long history of fighting what he considers "welfare handouts," was impressed with what he saw... and commented that this was the kind of giving he was in sympathy with because "it was given for doing something." The story is usually told with some glee at the fact that the liberal psychologist seems to have deceived Reagan. But I think Reagan may be the more perceptive one in this case. The token economy... follows an elitist system.... Decisions as to what behaviors should be reinforced very often depend on the creation of ward behavior that pleases ward personnel.... The question is whether the real client is the hospital establishment or the patient. (p. 417)

This was not, of course, just a story about a hospital token system; it was an allegory regarding the use of consequences in all walks of life. Not too long after finishing Pam's class, the passage quoted above came flashing back to me following Reagan's election as President of the United States. When Reagan indicated that his goal was to "replace programs enacted in the name of compassion that degrade the moral worth of work" (quoted in Pear, 1986), I understood that one possible meaning of "reform" was to employ aid, not for empowerment, but as a means of control.

This illustrates a key feature of Jim's perspective: He was deeply concerned about the use of contingencies wherever power differentials exist. This was true for obvious settings such as schools, prisons, and workplaces, but also for the larger societal system, emphasis upon which has important implications. For instance, Jim was an early advocate for shifting the focus of applied behavior analysis from problem remediation to problem prevention: "Although applied behaviorists have frequently focused on fixing individuals, the science of Behaviorism provides the means to analyze the structures, the system, and the forms of societal control that produce the "problems"" (Holland, 1978b, p. 163). Jim placed the word "problems" in quotation 
marks because he saw the emphasis on problem remediation as, in essence, a form of blaming the victim. He also pointed out that the very mechanisms that support applied behavior analysts in the "fixing" of individuals (e.g., salaried positions, grant funds, and, these days, lucrative insurance payment arrangements) stand to make them complacent with a system that causes "breaking" in the first place - perhaps even complicit in it. The proper focus for applied behavior analysis, he argued, should be on improving the social system - a perspective that anticipates later analyses of cultural evolution and meta-contingencies (e.g., Glenn, 1988) and also system-wide interventions like Positive Behavioral Interventions and Supports (Horner \& Sugai, 2015). In this regard Jim's papers (e.g., Holland, 1974, 1978) are not mere historical curiosities; they are as relevant today as when they were written, and should count as must-reads for anyone interested in understanding the role of a science and technology of behavior in the larger societal arena.

\section{Compliance with Ethical Standards}

Conflict of Interest The authors declare that he has no conflict of interest.

Ethical Statement This paper describes no new primary empirical work and as such is not subject to oversight by a research ethics body.

\section{References}

Doran, J., \& Holland, J. G. (1971). Eye movements as a function of response contingencies measured by the blackout technique. Journal of Applied Behavior Analysis, 4, 11-17.

Ferster, C. B., \& Skinner, B. F. (1957). Schedules of reinforcement. New York: Appleton-Century-Crofts.

Glenn, S. S. (1988). Contingencies and metacontingencies: toward a synthesis of behavior analysis and cultural materialism. The Behavior Analyst, 11, 161-179.

Goldiamond, I. (1974). Toward a constructional approach to social problems: ethical and constitutional issues raised by applied behavior analysis. Behavior, 2, 1-84.

Hake, D. F. (1982). The basic-applied continuum and the possible evolution of human operant social and verbal research. The Behavior Analyst, 5, 21-28.

Herrnstein, R. J. (1961). Relative and absolute strength of response as a function of frequency of reinforcement. Journal of the Experimental Analysis of Behavior, 4, 267-272.

Holland, J. G. (1957). Technique for behavioral analysis of human observing. Science, 125, 248-350.

Holland, J. G. (1958a). Counting by humans on a fixed-ratio schedule of reinforcement. Journal of the Experimental Analysis of Behavior, 1, 179-181.

Holland, J. G. (1958b). Human vigilance: the rate of observing an instrument is controlled by the schedule of signal detections. Science, 128, 61-67.

Holland, J. G. (1974). Political implications of applying behavioral psychology. In R. Ulrich, T. Stachnik, \& J. Mabry (Eds.), Control of human behavior, vol. 3: behavior modification in education (pp. 413-419). Glenview: Scott, Foresman, and Company.

Holland, J. G. (1975). Behavior modification for prisoners, patients, and other people as a prescription for the planned society. Mexican Journal of Behavior Analysis, 1, 81-95.

Holland, J. G. (1976). Ethical implications of behavior modification. Journal of Humanistic Psychology, 16(3), 71-78.

Holland, J. G. (1977). Behaviorism and the social system. In N. Datan \& H. W. Reese (Eds.), Life-span developmental psychology: dialectical perspectives on experimental research (pp. 311-316). New York: Academic Press.

Holland, J. G. (1978a). To Cuba with the Venceremos Brigade. Behaviorists for Social Action Journal, 1, $21-28$. 
Holland, J. G. (1978b). Behaviorism: part of the problem or part of the solution? Journal of Applied Behavior Analysis, 11, 163-174.

Holland, J. G., \& Skinner, B. F. (1961). The analysis of behavior: a program for self instruction. New York: McGraw Hill.

Holland, J. G., Solomon, C., Doran, J., \& Frezza, D. A. (1976). The analysis of behavior in planning instruction. Reading: Addison-Wesley Publishing Company.

Horner, R. H., \& Sugai, G. (2015). School-wide PBIS: an example of applied behavior analysis implemented at a scale of social importance. Behavior Analysis in Practice, 8, 80-85.

Lamarre, J., \& Holland, J. G. (1985). The functional independence of mands and tacts. Journal of the Experimental Analysis of Behavior, 43, 5-19.

Mace, F. C., \& Critchfield, T. S. (2010). Translational research in behavior analysis: historical traditions and imperative for the future. Journal of the Experimental Analysis of Behavior, 93, 293-312.

Nevin, J. A. (1969). Signal detection theory and operant behavior: a review of David M. Green and John A. Swets' Signal detection theory and psychophysics. Journal of the Experimental Analysis of Behavior, 12, 475-480.

Nevin, J. A. (2008). Stimuli, reinforcers, and private events. The Behavior Analyst, 31, 113-126.

Nuzzolo-Gomez, R., \& Greer, R. D. (2004). Emergence of untaught mands or tacts with novel adjective-object pairs as a function of instructional history. The Analysis of Verbal Behavior, 24, 30-47.

Pear, R. (1986, February 5). Reagan seeks welfare plan to free poor from government dependency. New York Times. Retrieved from http://www.nytimes.com/1986/02/05/us/reagan-seeks-welfare-plan-to-free-poorfrom-government-dependency.html.

Perone, M., \& Baron, A. (1980). Reinforcement of human observing behavior by a stimulus correlated with extinction or increased effort. Journal of the Experimental Analysis of Behavior, 34, 239-261.

Rutherford, A. (2000). Radical behaviorism and psychology's public: BF Skinner in the popular press, 1934 1990. History of Psychology, 3, 371-395.

Schroeder, S., \& Holland, J. G. (1968). Operant control of eye movements during human vigilance. Science, 161, 292-293.

Schroeder, S. R., \& Holland, J. G. (1969). Reinforcement of eye movements with concurrent schedules. Journal of the Experimental Analysis of Behavior, 12, 897-903.

Wildemann, D. G., \& Holland, J. G. (1972). Control of a continuous response dimension by a continuous stimulus dimension. Journal of the Experimental Analysis of Behavior, 18, 419-434.

Winett, R. A., \& Winkler, R. (1972). Current behavior modification in the classroom: be still, be quiet, be docile. Journal of Applied Behavior Analysis, 5, 499-504.

Wolf, M. M. (1978). Social validity: the case for subjective measurement or how applied behavior analysis is finding its heart. Journal of Applied Behavior Analysis, 11, 203-214. 